\title{
Application of Response Surface Methodology for Optimization of Mushroom Saccharification using Crude Enzymatic Extract from Solid-State Fermentation of Pineapple Peels by Aspergillus niger KWM
}

Daniel Otieno Ojwang ( $\nabla$ daniel.otieno@kirdi.go.ke )

Kenya Industrial Research and Development Institute https://orcid.org/0000-0002-2666-3449

Mulaa F. Jakim

University of Nairobi

George Obiero

University of Nairobi

Jacob Midiwo

University of Nairobi

\section{Research Article}

Keywords: Bioprocessing, Fruit waste, Pleurotus sp, RSM, Solid-state fermentation

Posted Date: April 21st, 2021

DOl: https://doi.org/10.21203/rs.3.rs-442666/v1

License: (c) (i) This work is licensed under a Creative Commons Attribution 4.0 International License. Read Full License 


\section{Abstract}

Mushrooms are a rich source of high value compounds. Efficient enzymatic degradation of mushroom cell-wall matrix is therefore critical in the recovery of cellular components in high yields. In the present study, the effect of reaction variables on mushroom saccharification using crude enzymatic extract was evaluated and optimized using the central composite design based on the response surface methodology. The crude extract displayed CMCase, Fpase and xylanase activities of $1.23 \mathrm{Umg}^{-1}$ protein, $0.95 \mathrm{Umg}^{-1}$ protein and $1.52 \mathrm{Umg}^{-1}$ protein. The model was validated by the analysis of variance with a coefficient of determination of 0.866 and $F$ test value of 7.39 , making the model valid at the $95 \%$ confidence limit. The model achieved glucose yield of $1.490 \mathrm{mg} / \mathrm{mL}$ at $\mathrm{pH} 6.5$, temperature $50^{\circ} \mathrm{C}$, enzyme load of $5 \%(\mathrm{v} / \mathrm{v})$ and reaction time of $12 \mathrm{~h}$. The experiment using optimal model conditions yielded 1.582 $\mathrm{mg} / \mathrm{mL}$ glucose which is 1.1 folds higher than the predicted model value. This study demonstrated potential of crude extract from solid-state fermentation of low-cost pineapple peels in mushroom processing.

\section{Introduction}

Edible mushrooms are nutritious food items rich in health promoting compounds. Traditionally, mushrooms were not only eaten for their nutritional value but also for treatment of various illnesses [1, 2]. Currently, mushrooms have received widespread application in the production of conventional medicine due to their high content of biologically active substances [3]. These compounds include hemicelluloses, polysaccharides, lipopolysaccharides, peptides, proteins, glycoproteins, nucleosides, triterpenoids, complex starches, lectins, and lipid derivatives [4]. In addition, mushrooms are also high in alkaloids, saponins, flavonoids, tannins, sterols, triterpenes, coumarins and cyanogenic glycosides $[5,6]$. These compounds have potent immunomodulatory, anticancer, antiproliferative, anti-inflammatory, antiviral, hypotensive and antithrombotic activities [7, 8].

The choice of extraction techniques is important in maintaining quality of biologically active compounds from mushrooms for specific applications in food, pharmaceutical and cosmetic industries. The conventional extraction techniques have involved the use of toxic and highly inflammable solvents which have adverse effects in the environment and the quality of the final products [9]. Enzyme-based extraction technique is considered therefore, a viable alternative to the solvent-based extraction methods [10]. The use of enzymes in industrial processing does not cause adverse effect on the environment and the quality of the final product [11]. However, despite many advantages, low product recovery, long extraction period and high cost of commercial enzymes are some of the major bottlenecks associated with enzymebased processing [12].

In an attempt to improve the commercial viability of industrial processing using enzymes, the use of low cost crude enzymatic extracts from the microbial fermentation of agro-waste materials is increasingly being adopted [13]. This is because crude extracts from the fermented lignocellulosic biomass contain enzyme mixtures capable of hydrolyzing many biomaterials [14]. In fact, in certain instances crude 
enzymatic extracts have proved to be more efficient compared to the commercial enzymes under optimized reaction conditions $[15,16]$. The traditional one-variable-at-a-time method has widely been used in many optimization processes; however, it certain limitations including need for a number of experiments to be performed and is also time consuming [17]. A response surface methodology which is a mathematical and statistical tool has been developed and is currently used in the modeling and optimizing reaction parameters to achieve maximum response [18-20]. In the present study, a central composite design based on the response surface methodology was used to evaluate and optimize effect of reaction parameters (medium $\mathrm{pH}$, reaction time, reaction temperature and enzyme loading) on the glucose yield during saccharification of mushroom biomass using crude enzymatic extract.

\section{Materials And Method}

\section{Microorganism and culture condition}

A stock culture of Aspergillus niger KWM, was propagated on potato dextrose agar at $30{ }^{\circ} \mathrm{C}$ for 5 days. The conidia from the sporulating plate cultures were suspended in $5 \mathrm{~mL}$ of sterile water and $1 \mathrm{~mL}$ $\left(\sim 1.0 \times 10^{7}\right.$ spores $\left./ \mathrm{mL}\right)$ of the spore suspension was transferred to a $250-\mathrm{mL}$ Erlenmeyer flask containing $50 \mathrm{~mL}$ of the basal medium. The medium was composed of: $1 \%(\mathrm{w} / \mathrm{v}) \mathrm{KH}_{2} \mathrm{PO}_{4}, 1 \%(\mathrm{w} / \mathrm{v}) \mathrm{MgSO}_{4} .7 \mathrm{H}_{2} \mathrm{O}$, $0.005 \%(\mathrm{w} / \mathrm{v}) \mathrm{CaCl} .2 \mathrm{H}_{2} \mathrm{O}, 4 \%$ (w/v) NaCl, $1 \%(\mathrm{w} / \mathrm{v}) \mathrm{Na}_{2} \mathrm{CO}_{3}, 1 \%(\mathrm{w} / \mathrm{v}) \mathrm{NH}_{4} \mathrm{SO}_{4}$ and $0.1 \%(\mathrm{v} / \mathrm{v})$ Tween 80. The medium culture was incubated at $30^{\circ} \mathrm{C}$ at an agitation speed of $120 \mathrm{rpm}$ in an orbital shaker (Gerhardt, $\mathrm{GmbH}$, Germany) for 5 days.

\section{Solid-state fermentation of pineapple peels}

The pineapple (Ananas cosmosus, Linn.) peels were obtained from the local fruit vendor and dried in an electric oven to $\sim 5 \%(\mathrm{w} / \mathrm{w})$ moisture content. The dried peels were then milled using a laboratory blender (Sumeet Inc., Mumbai, India) into fine powder (mesh size 32). The dried powder (10g) was put into $250 \mathrm{~mL}$ Erlenmeyer flask and moistened with basal salt solution and then was autoclaved $121^{\circ} \mathrm{C}$ for 30 min. The substrate was inoculated with $1 \mathrm{~mL}$ of spore suspension, and the culture medium was then incubated at $30^{\circ} \mathrm{C}$ for 7 days. The substrate bed was suspended in $50 \mathrm{mM}$ phosphate buffer, $\mathrm{pH} 6.8$ and agitated at 200rpm in an orbital shaker (Gerhardt, $\mathrm{GmbH}$, Germany) for $1 \mathrm{~h}$. The mixture was centrifuged at $5000 \mathrm{rpm}$ for $10 \mathrm{~min}$ at $4 \circ \mathrm{C}$. The total protein content of the supernatant was estimated by the method of Lowry et al. [21] using BSA as a standard.

\section{Enzyme assays}

The CMCase activity of the crude extract was determined by mixing $490 \mu \mathrm{L}$ of carboxymethyl cellulose (CMC) solution ( $1 \%, \mathrm{w} / \mathrm{v}$ CMC prepared in $50 \mathrm{mM}$ phosphate buffer, $\mathrm{pH} 6.0$ ) and $10 \mu \mathrm{L}$ of crude enzymatic extract. Similarly, xylanase activity was determined by mixing solutions of Beechwood xylan prepared in citrate buffer. Filter paperase (Fpase) activity was determined by adding small pieces ( 50mg) of Whatman filter paper no. 1 to appropriately diluted crude extract. The mixtures were incubated at $50^{\circ} \mathrm{C}$ for 
60min. Glucose content of the CMC and filter paper degradation were determined using DNS method [22]. Similarly, the xylose content of the Beechwood xylan degradation was determined. The standard graphs were prepared using $0-500 \mu \mathrm{g}$ of glucose for $\mathrm{CMC}$ and filter paper degradation. The standard graph of $0-500 \mu \mathrm{g}$ xylose was used for xylan degradation. One unit of enzyme activity is defined as the amount of enzyme that catalyzes the release of $1 \mu \mathrm{mol}$ of reducing sugar equivalent per minute under the specified assay conditions.

\section{Modeling reaction parameters for enzymatic saccharification}

The Minitab software (Minitab, Inc., Penn, USA) was used to build and analyze the experimental design. The central composite design was used for evaluating the effect of reaction variables on mushroom saccharification. The response surface methodology was used for optimizing reaction variables to achieve maximum response (glucose yield).

\section{Mushroom hydrolysis using crude enzymatic extract}

Preliminary research was undertaken to identify key reaction variables that affect the enzymatic hydrolysis of lignocellulosic biomass including mushrooms [23]. In order to initiate enzymatic hydrolysis, $200 \mathrm{mg}$ of powdered Pleurotus ostreatus was incubated in crude extract (prepared in 50mM phosphate buffer, $\mathrm{pH} 4.5-6.5)$, at temperatures $30-50^{\circ} \mathrm{C}$ for up to $60 \mathrm{~h}$, as per the experimental design. Aliquot ( $\left.1 \mathrm{~mL}\right)$ was removed at predetermined time intervals and immediately $3 \mathrm{~mL}$ of DNS reagent was added and heated at $80^{\circ} \mathrm{C}$ for $5 \mathrm{~min}$. The mixture was then centrifuged at $5000 \times \mathrm{g}$ for $10 \mathrm{~min}$. Time zero samples were collected before the addition of the crude extract and used as blank. The glucose concentration was determined using spectrophotometer at 540nm.

\section{Statistical analysis}

The $\mathrm{F}$ test was used to interpret the coefficients and the significance of each model term was determined by the analysis of variance (ANOVA). The student's t-test was performed to determine the significance of the regression coefficients. The contour plot and regression analysis were performed to establish the optimal conditions for mushroom saccharification using crude enzymatic extract for maximum glucose yield.

\section{Results And Discussion}

\section{Enzyme activities of the crude extract}

The solid-state fermentation of pineapple peels using A.niger KWM yielded crude extract with protein content of $145 \mathrm{mg} \mathrm{mL}^{-1}$. This is indicated that the fungus released extra cellular enzymes onto the growth medium during fermentation. The choice of growth 
substrate is critical as it influences specific enzyme production during microbial fermentation of lignocellulosic biomass [24]. The pineapple peels used as fermentation medium influenced the enzymes mixtures capable of hydrolyzing pineapple peel substrate. The crude extract displayed enzyme activities of $175 \mathrm{UmL}^{-1}, 138 \mathrm{UmL}^{-1}$ and $221 \mathrm{UmL}^{-1}$ for CMCase, Fpase and xylanase respectively. Most filamentous fungi have been reported to produce cellulase and xylanase enzymes with either low or high activities [25-27]; however, this study showed that solid-state fermentation of pineapple peels using A.niger KWM can potentially produce enzyme cocktail with relatively close cellulase and xylanase activities which is important in many industrial bioprocesses.

\section{Optimizing mushroom saccharification parameters for higher glucose yield}

In the present study, the $\mathrm{pH}$ range of 4.5-6.5, reaction time ranging from $12-60 \mathrm{~h}$, temperature range of $30-50^{\circ} \mathrm{C}$ and enzyme loading of $1-5 \%(\mathrm{v} / \mathrm{v})$ were chosen as key independent variables that affect enzymatic saccharification of mushroom biomass. Table 1 illustrates the coded and real values for the experimental variables.

Table 1 Coded and real values of reaction variables for central composite design

A second-order polynomial model that describes the effect of variables on glucose yield from the enzymatic saccharification of mushroom is presented in Eq 1.

$$
\begin{aligned}
& Y_{(\text {Glucose yield })}=\beta_{0}+\beta_{1} x_{1}+\beta_{2} x_{2}+\beta_{3} x_{3}+\beta_{4} x_{4}+\beta_{11}+\beta_{22}+\beta_{33}+\beta_{44}+\beta_{12} x_{1} x_{2}+ \\
& \beta_{13} x_{1} x_{3}+\beta_{14} x_{1} x_{4}+\beta_{23} x_{2} x_{3}+\beta_{24} x_{2} x_{4}+\beta_{34} x_{3} x_{4}
\end{aligned}
$$

where $Y$ is the measured response; $\beta_{0}$ is the intercept term; $\beta_{1}, \beta 2, \beta_{3}$, and $\beta_{4}$ are linear coefficients; $\beta_{11}, \beta_{22}, \beta_{33}$, and $\beta_{44}$ are quadratic coefficients; $\beta_{12}, \beta_{13}, \beta_{14}, \beta_{23}, \beta_{24}$, and $\beta_{34}$ are interaction coefficients; and $\mathrm{x}_{1}, \mathrm{x}_{2}, \mathrm{x}_{3}$, and $\mathrm{x}_{4}$ represent the independent variables (temperature, $\mathrm{pH}$, time and enzyme loading) respectively. In developing the regression equation, the test variables for glucose yield were coded according to Eq 2 .

$$
\mathrm{x}_{\mathrm{i}}=\frac{X i-x 0}{\Delta X i}
$$


where $x_{i}$ is the coded value, $X_{i}$ is the real value of the independent variable, $X_{0}$ is the value of the independent variable on the center point, and $\Delta \mathrm{X}_{\mathrm{i}}$ is the step change value.

The CCD and their coded, experimental and predicted values are shown in Table 2 . The model predicted maximum glucose yield of $0.934 \mathrm{mg} / \mathrm{mL}$ under the reaction conditions of $\mathrm{pH}$ 6.0, temperature $45^{\circ} \mathrm{C}$ and enzyme loading of $4 \%(\mathrm{v} / \mathrm{v})$ for a period of $48 \mathrm{~h}$ (run 16). Experiments done under these conditions yielded slightly higher glucose $(0.945 \mathrm{mg} / \mathrm{mL})$. The reaction at $\mathrm{pH} 5.5$, temperature $40^{\circ} \mathrm{C}$ and enzyme loading of $5 \%(\mathrm{v} / \mathrm{v})$ for a period of $36 \mathrm{~h}$ yielded $1.046 \mathrm{mg} / \mathrm{mL}$ (run 24); this was 2.8 folds higher than the glucose yield predicted by the model.

Table 2 Matrix of the CCD for the evaluation of the effect of independent variables on the glucose yield during mushroom saccharification

The model expressed by equation (3) represents glucose yield $(\mathrm{Y})$ as a function of $\mathrm{pH}\left(\mathrm{X}_{1}\right)$, time $\left(\mathrm{X}_{2}\right)$, temperature $\left(\mathrm{X}_{3}\right)$, and enzyme loading $\left(\mathrm{X}_{4}\right)$.

$\mathrm{Y}_{(\text {Glucose yield })}=0.367714+0.044625 \mathrm{x}_{1}+0.062208 \mathrm{x}_{2}+0.117292 \mathrm{x}_{3}+0.147958 \mathrm{x}_{4}{ }^{-}$

$$
\begin{aligned}
& 0.041085-0.019710+ \\
& 0.022290+0.081415-.028438 \mathrm{x}_{1} \mathrm{x}_{2}+0.025438 \mathrm{x}_{1} \mathrm{x}_{3}+0.012062 \mathrm{x}_{1} \mathrm{x}_{4}-0.005563 \mathrm{x}_{2} \mathrm{x}_{3} \\
& +0.052563 \mathrm{x}_{2} \mathrm{x}_{4}-0.094938 \mathrm{x}_{3} \mathrm{x}_{4}
\end{aligned}
$$

Table 3 illustrates the significance of all terms in the polynomial equation (2) as described statistically by F-test and the analysis of variance for response surface quadratic model.

Table 3 Analysis of variance of second order polynomial model for optimization of enzymatic mushroom saccharification.

Values of probability $(p) \square \mathrm{F}<0.05$ indicated that the model terms were significant. The Fvalue of 7.39 and a low $p$-value $(p=0.000)$ suggest that the model is significant. The coefficient of determination $\left(\mathrm{R}^{2}=86.6 \%\right)$ indicated that the experimental and predicted values were in good agreement, and that the model can well be used to predict process 
performance and optimization. The lack-of-fit (F-value of 1.10) for regression of Eq. 3 was not significant ( $p$-value $=0.475$ ). Non-significant lack-of-fit is good proof that the model equation is adequate to predict the response under any combination of values of the variables. The linear and quadratic terms in second order polynomial model (Eq. 3) were highly significant $(\mathrm{p}<0.01)$ and adequate to represent the relationship between glucose yield and the reaction variables of $\mathrm{pH}$, enzyme loading, temperature and time (Table 3).

The $t$ and p-values for linear, quadratic and combined effects of the variables are given in Table 4. The time, temperature and enzyme loading were linear variables which had significant $(\mathrm{p}<0.05)$ positive effects on mushroom hydrolysis. The medium $\mathrm{pH}$ had nonsignificant $(p>0.05)$ positive effect on mushroom hydrolysis. With regard to the quadratic terms, the medium $\mathrm{pH}$ and reaction time had negative effect on the glucose levels obtained. The temperature and enzyme loading positively (positive coefficients) affected mushroom hydrolysis and the glucose yield. The effect of enzyme loading on glucose yield was significant $(p<0.05)$. The absence of interactions between the variables $(p>0.05)$ implies that these variables had additive effects on mushroom hydrolysis. Similar results had been reported where non-interactive effect of reaction variables resulted in additive effects on the response [28].

Table 4 Estimated regression coefficients of second order polynomial model for optimization of glucose yield

\section{Interaction effect of variables on enzymatic saccharification of mushroom biomass}

To analyze the interaction and to determine the optimum value of each variable for maximum glucose yield, three dimensional response surface curves were drawn against two experimental variables while keeping the other variables constant at their central points. The interaction effect of reaction temperature and enzyme loading on glucose is illustrated in Figure 1. According to this contour plot, the glucose yield $1.50 \mathrm{mg} / \mathrm{mL}$ is achievable under the enzyme loading of $4.8-5.0 \%(\mathrm{v} / \mathrm{v})$ and temperature range $48-50^{\circ} \mathrm{C}$ while keeping time and $\mathrm{pH}$ constant at $36 \mathrm{~h}$ and 5.5 respectively. 
Fig. 1 Response surface plot of the combined effect of reaction time and enzyme concentration on glucose yield.

Figure 2 shows the interaction effect of the reaction time and enzyme loading on glucose yield. Glucose yield of 1.00-1.25mg/mL can be obtained under the enzyme loading of 4.8$5.0 \%(\mathrm{v} / \mathrm{v})$ and reaction time $\square 40 \mathrm{~h}$ while keeping the temperature and $\mathrm{pH}$ constant at $40^{\circ} \mathrm{C}$ and 5.5 respectively.

Fig. 2 Response surface plot of the combined effect of time and enzyme loading on glucose yield

According to the contour plot in Figure 3, mushroom hydrolysis at the temperature range of $30^{\circ} \mathrm{C}-60^{\circ} \mathrm{C}$ for $12 \mathrm{~h}$ to $60 \mathrm{~h}$ while keeping $\mathrm{pH}$ and enzyme loading constant at 5.5 and $3 \%$ $(\mathrm{v} / \mathrm{v})$ respectively is yields $0.5-0.75 \mathrm{mg} / \mathrm{mL}$ glucose. The increase in temperature has been reported to have effects on the enzyme activity as a result of increasing thermal activation [29- 30].

Fig. 3 Response surface plot of the combined effect of temperature and time on glucose yield

According to Figure 4, glucose yield of $0.75-1.00 \mathrm{mg} / \mathrm{mL}$ can be achieved when mushroom hydrolysis is done under pH 5.8-6.5 and enzyme loading 4.5-5.0\% (v/v), while keeping time and temperature constant at $36 \mathrm{~h}$ and $40^{\circ} \mathrm{C}$ respectively. It suggests that the enzymes in the crude extract are able to adapt well to the $\mathrm{pH}$ range of 5.8 to 6.5. Enzyme concentration is an important factor in the enzymatic saccharification of lignocellulosic biomass [31].

Fig. 4 Response surface plot of the combined effect of enzyme load and temperature on glucose yield

Figure 5 shows the interaction effect of medium $\mathrm{pH}$ and reaction temperature on glucose yield. Hydrolysis of mushroom at temperature range of $48-50^{\circ} \mathrm{C}$ and $\mathrm{pH}$ range $4.8-6.5$ while keeping enzyme loading at $3 \%(\mathrm{v} / \mathrm{v})$ for $36 \mathrm{~h}$ respectively yields glucose of $0.5-0.75 \mathrm{mg} / \mathrm{mL}$.

Fig. 5 Response surface plot of the combined effect of $\mathrm{pH}$ and time on glucose yield 
Figure 6 shows the interaction effect of medium $\mathrm{pH}$ and temperature on glucose yield. Glucose yield of $0.25-0.5 \mathrm{mg} / \mathrm{mL}$ can be achieved when mushroom hydrolysis is performed at $\mathrm{pH}$ 1.0-6.5 and temperature $40-50^{\circ} \mathrm{C}$ while keeping time and enzyme loading constant at $36 \mathrm{~h}$ and $3 \%(\mathrm{v} / \mathrm{v})$ respectively.

Fig. 6 Response surface plot of the combined effect of temperature and time on glucose yield

\section{Model validation}

Figure 7 illustrates that enzymatic saccharification of mushroom biomass at temperature $50^{\circ} \mathrm{C}$, medium $\mathrm{pH} 6.5$, and enzyme loading of $5 \%(\mathrm{v} / \mathrm{v})$ for $12 \mathrm{~h}$ yields $1.490 \mathrm{mg} / \mathrm{mL}$ of glucose. The experiments conducted using optimal model conditions yielded glucose $1.582 \mathrm{mg} / \mathrm{mL}$ which is 1.1 folds higher than the predicted value. This confirms the validity of the model as a viable tool that may be used for modeling and optimizing reaction parameters for mushroom hydrolysis using crude enzymatic extract. The glucose yield is likely to even increase with mushroom pretreatment and optimization of other reaction parameters such as agitation speed during enzymatic processing [32, 33].

Fig. 7 Optimization plot for enzymatic saccharification of mushroom

The glucose yield of $1.582 \mathrm{mg} / \mathrm{mL}$ reported in the present study is within the range of glucose content of Pleurotus species previously reported [34, 35]. The hydrolysis of mushroom biomass was attributed to the ability of the crude extract to display adequate balance between the activities of $\beta$-glucosidase, FPase, and cellobiohydrolase which are key in mushroom cell-wall degradation [36-37]. An enzyme ratio of 2:1 for FPase and $\beta$ glucosidase enzymes is regarded as defining a suitable enzyme system [38].

Commercial enzymes have been used in mushroom processing to recover high value products. Ang and Ismail-Fitry [39] and Banjongsinsiri et al. [40] used commercial bromelain and papain enzymes respectively to enhance recovery of protein from mushroom. Similarly, Poojary et al [41] digested mushroom biomass with commercial enzymes to recover amino acids responsible for umami taste. The processing of mushrooms 
using commercial enzymes of some mushroom species such as Shiitake have been patented [42]. However, for a long time, the cost of commercial enzymes has remained a major bottleneck in industrial bioprocessing. The application of crude enzymatic extracts in bioconversion processes has been therefore driven majorly by the need to make enzymebased processing more cost-effective and competitive. Mahamud \& Gomes [43] applied crude enzymatic extract for saccharification of sugarcane bagasse in bioethanol production; crude extracts showed higher saccharification efficiency compared to their commercial counterparts. The use of crude enzymatic extract has also been extended in many industrial bioprocesses including fruit processing industries for fruit juice clarification $[44,45]$. Despite increasing research outputs in the applications of crude enzymatic extracts in industrial bioprocessing, the information on mushroom processing using crude enzymes is quite limited or probably not available.

\section{Conclusions}

The solid-state fermentation of pineapple peels using A.niger KWM produced enzyme mixtures capable of hydrolyzing mushroom cell-wall matrix. Besides, the solid-state fermentation of low-cost pineapple peels is potentially cost-effective strategy of obtaining enzyme for mushroom processing at an industrial scale; an approach that offers the promise of significant advances that can remarkably make mushroom processing using enzymes more competitive. The response surface methodology proved to be a reliable tool for predicting process performance of mushroom saccharification using crude enzymatic extracts.

\section{Declarations}

Funding This study did not have any grant funding

Data Availability All data are fully available without restriction.

\section{Compliance with ethical standards}

Competing interests The authors declare that they have no competing interests.

Ethics Approval and Consent to Participate This article does not contain any studies with human participants or animals performed by any of the authors.

Consent for Publication This study does not contain any individual person's data.

\section{References}


1. Boa, E. (2004). Wild edible fungi, a global overview of their use and importance to people. Rome: Non-wood forest products 17: FAO.

2. Borchers, A. T., Stern, J. S., Hackman R.M., Keen, C. L., \& Gershwin, M. E. (1999). Mushrooms, tumors and immunity. Proceedings of the Society for Experimental Biology and Medicine, 221(4), 281-293.

3. Adebayo, E. A., Oloke J. K., Ayandele, A. A., \& Adegunlola, C. O. (2012). Phytochemical, antioxidant and antimicrobial assay of mushroom metabolite from Pleurotus pulmonarius. Journal of Microbiology and Biotechnology Resources, 2(2), 366-374.

4. Kalač, P. (2009). Chemical composition and nutritional value of European species of wild growing mushrooms: a review. Food Chemistry, 113(1), 9-16.

5. Ito, N., Hirose, M., Fukushima, S., Tsuda, H., Shirai, T., \& Tatematsu, M. (1986). Studies on antioxidants: their carcinogenic and modifying effects on chemical carcinogenesis. Food and Chemical Toxicology, 24(10-11), 1071-1082.

6. Lindequist, U., Niedermeyer, T. H. J., \& Jülich, W. D. (2005). The pharmacological potential of mushrooms. Evidence-based Complementary and Alternative Medicine, 2(3), 285-289

7. Xu” Beelman, R. B., \& Lambert, J. D. (2012). The cancer preventive effects of edible mushrooms. Anticancer Agents and Medicinal Chemistry, 12(10):1255-63.

8. Cheung, P. C. K. (2008). Nutritional value and health benefits of mushrooms. In P. C. K. Cheung (Ed.), Mushrooms as Functional Foods. Wiley, Hoboken, 71-110.

9. Max, M. H., Jay, A., \& Siegel, A. (2015). Fires and Explosions. In M. H. Max., Jay., \& A. Siegel (Eds.), Fundamentals of Forensic Science (3rd Ed), Academic Press, 451-490

10. Puri, M., Sharma, D., \& Barrow, C. J. (2012). Enzyme-assisted extraction of bioactives from plants. Trends in Biotechnology, 30(1), 37-44.

11. Latif, S., \& Anwar, F. (2009). Effect of aqueous enzymatic processes on sunflower oil quality. Journal of the American Oil Chemists' Society, 86(4), 393-400

12. Arnau, J., Yaver, D., Hjort, C. M. (2019). Strategies and Challenges for the Development of Industrial Enzymes Using Fungal Cell Factories. Grand Challenges in Fungal Biotechnology, 179-210.

13. Dale, B. E. (1999). Biobased industrial products: bioprocess engineering when cost really counts. Biotechnology Programs, 15: 775-776.

14. Gabriela, P. M., Evan, M.V., Rafael, F. A., Bráulio R. G. N., Guilherme, G. C., Adriane, F. M., et al. (2015). The influence of pretreatment methods on saccharification of sugarcane bagasse by an enzyme extract from Chrysoporthe cubensis and commercial cocktails: A comparative study. Bioresource Technology, 192, 670- 676

15. Griggs, A. J., Stickel, J. J., \& Lischeske, J. J. (2012). A mechanistic model for enzymatic saccharification of cellulose using continuous distribution kinetics II: cooperative enzyme action, solution kinetics, and product inhibition, Biotechnology and Bioengineering, 109(3), 676-685.

16. Hajji, M., Rebai, A., Gharsallah, N., \& Nasri, M. (2008). Optimization of alkaline protease production by Aspergillus clavatus ES1 in Mirabilis jalapa tuber powder using statistical experimental design. 
Applied Microbiology and Biotechnology, 79(6), 915-923.

17. Panda, B. P., Ali, M., \& Javed, S. (2007). Fermentation Process Optimization. Research Journal of Microbiology, 2: 201-208.

18. Geiger, E. O. (2014) Statistical Methods for Fermentation Optimization. In. C. H. Vogel, C. M. Todaro (Eds.) Fermentation and Biochemical Engineering Handbook ( $\left.3^{\text {rd }}\right)$, William Andrew Publishing

19. Braga, F. R., Araújo, J. V., Soares, F. E. F., Araujo, J. M., Geniêr, H. L. A., Silva, A. R., et al. (2011). Optimizing protease production from an isolate of the nematophagous fungus Duddingtoniaflagrans using response surface methodology and its larvicidal activity on horse cyathostomins. Journal of Helminthology, 85(2), 164-170.

20. Singh, G., Ahuja, N., Sharma, P., \& Capalash, N. (2007). Response surface methodology for the optimized production of an alkalophilic laccase from y-proteobacterium JB. BioResources, 4(2), 544553.

21. Lowry, O. H., Rosebrough, N. J., Farr, A. L., \& Randall, R. J. (1951). Protein measurement with the Folin phenol reagent. The Journal of Biological Chemistry, 93(1), 265-275.

22. Miller, G. L. (1959). Use of dinitrosalicylic acid reagent for determination of reducing sugar. Analytical Chemistry, 31(3), 426-428.

23. Adrio, J. L., Demain, A. L. (2014). Microbial enzymes: tools for biotechnological processes. Biomolecules, 4(1):117-139.

24. Elisashvili, V., Kachlishvili, E., Penninckx, M. (2008). Effect of growth substrate, method of fermentation, and nitrogen source on lignocellulose-degrading enzymes production by white-rot Basidiomycetes. Journal of Indian Microbiology and Biotechnology, 35(11):1531-8.

25. Attri, S., \& Garg, G. (2014). Isolation of microorganisms simultaneously producing Xylanase, pectinase and cellulase enzymes using cost effective substrates. Journal of innovative biology. 1(1), 45-50.

26. Kumar, A., Gautam, A., \& Dutt, D. (2015). Screening of Fungal Resources for the Production of Cellulases and Xylanases. British Biotechnology Journal, 9(1), 1-13.

27. Ja'afaru, M. I. (2013). Screening of Fungi Isolated from Environmental Samples for Xylanase and Cellulase Production. Microbiology, 2013(3).

28. de Almeida, J. M \& de Lima, V. A., de Lima, P. C. G. \& Knob, A. (2016). Effective and low-cost saccharification of pineapple peel by Trichoderma viride crude extract with enhanced $\beta$-Glucosidase Activity. Bioenergy Research, 2-11.

29. Peterson, M.E., Daniel, R.M., Danson, M.J \& Eisenthal, R. (2007). The dependence of enzyme activity on temperature: determination and validation of parameters. Biochemistry Journal. 402, 331-337.

30. Daniel, R.M. \& Danson, M.J. (2013). Temperature and the catalytic activity of enzymes: A fresh understanding. FEBS Letters, 587(2013), 2738-2743.

31. Yang, B., Dai, Z., Ding, S-Y., Wyman, C. E. (2011). Enzymatic hydrolysis of cellulosic biomass. Biofuels, 2(4):421-450. 
32. Chen, Y., Stevens, M. A., Zhu, Y., Holmes, J., \& Xu, H. (2013). Understanding of alkaline pretreatment parameters for corn stover enzymatic Saccharification. Biotechnology for Biofuels, 8(6), 1-10.

33. Chen, H., \& Wang, L. (2017). Enzymatic Hydrolysis of Pretreated Biomass. In H. Chen, \& L. Wang (Eds.), Technologies for Biochemical Conversion of Biomass. Academic Press, 65-99.

34. Sławińska, A., Jabłońska-Ryś, E., \& Stachniuk, A. (2020). High-Performance Liquid Chromatography Determination of Free Sugars and Mannitol in Mushrooms Using Corona Charged Aerosol Detection. Food Analytical Methods, 14(2021), 209-216.

35. Zhou, S., Tang, Q., Luo, X., Xue, J., Liu, Y., et al. (2012). Determination of Carbohydrates by High Performance Anion Chromatography-Pulsed Amperometric Detection in Mushrooms. International Journal of Medicinal Mushroom, 14(4), 411-17.

36. Tudzynski, P., \&Sharon, A. (2003). Fungal Pathogenicity Genes. In D. K. Arora, \& G. G. Khachatourians (Eds.), Applied Mycology and Biotechnology. Elsevier, 3, 87-212.

37. Kubicek, C. P., Starr, T. L., \& Glass, N. L. (2014). Plant Cell Wall-Degrading Enzymes and Their Secretion in Plant-Pathogenic Fungi. Annual Review of Phytopathology, 52(1), 427-451.

38. Ouyang, J., Li, X., Ying, H., Yong, Q. (2009). Enhanced enzymatic conversion and glucose production via two-step enzymatic hydrolysis of corn cob residue from xylooligosaccharides producer's waste. BioResources, 4(4):1586-1599.

39. Ang, S. S., \& Ismail-Fitry, M. R. (2019). Production of Different Mushroom Protein Hydrolysates as Potential Flavourings in Chicken Soup Using Stem Bromelain Hydrolysis. Food Technology and Biotechnology, 57(4), 472-480.

40. Banjongsinsiri, P., Pasakawee, K., Noojuy, N., Taksima, T., \& Rodsuwan, U. (2016). Production of mushroom protein hydrolysates by enzymatic hydrolysis and their physicochemical properties. Food and Applied Bioscience Journal, 4(3), 161-170

41. Poojary, M. M., Orlien, V., Passamonti, P., Oslen, K. (2017). Enzyme-assisted extraction enhancing the umami taste amino acids recovery from several cultivated mushrooms. Food Chemistry, 1(234), 236244.

42. Weliang, W., Wenfeng, S., Zhiqing, G., Zhixiang, X., Wenjia, C., Fengjuan, J., Yansheng, W., Kang, S. (2016). Enzyme hydrolysis method of shiitake mushrooms. Patent No. CN201611232966.3A.

43. Mahamud, M. R. \& Gomes, D. J. (2012). Enzymatic Saccharification of Sugar Cane Bagasse by the Crude Enzyme from Indigenous Fungi. Journal of Scientific Research, 4 (1), 227-238.

44. Kumar, S., \& Sharma, H. K. (2012). Comparative effect of crude and commercial enzymes on the juice recovery from pineapple (Ananas comosus) using principal component analysis (PCA). Food Science and Biotechnology, 2, 959-67.

45. Patidar, M. K., Nighojkar, S., Kumar, A., \& Nighojkar, A. (2018). Pectinolytic enzymes-solid state fermentation, assay methods and applications in fruit juice industries: a review. 3 Biotech, 8(4), 199.

\section{Tables}


Table 1

\begin{tabular}{lllllll}
\hline Independent variables & Symbol & \multicolumn{5}{c}{ Coded levels } \\
\cline { 3 - 7 } & & -2 & -1 & 0 & 1 & 2 \\
\hline $\mathrm{pH}$ & $\mathrm{X}_{1}$ & 4.5 & 5.0 & 5.5 & 6.0 & 6.5 \\
Time $(\mathrm{h})$ & $\mathrm{X}_{2}$ & 12 & 24 & 36 & 48 & 60 \\
Temperature $\left({ }^{\circ} \mathrm{C}\right)$ & $\mathrm{X}_{3}$ & 30 & 35 & 40 & 45 & 50 \\
Enzyme loading $(\% \mathrm{v} / \mathrm{v})$ & $\mathrm{X}_{4}$ & 1 & 2 & 3 & 4 & 5 \\
\hline
\end{tabular}

Table 2

\begin{tabular}{|l|l|l|l|l|c|c|}
\hline Std Order & $\mathrm{X}_{1}$ & $\mathrm{X}_{2}$ & $\mathrm{X}_{3}$ & $\mathrm{X}_{4}$ & \multicolumn{2}{|c|}{ Glucose yield(mg/mL) } \\
\cline { 6 - 8 } & & & & & Experimental & Predicted \\
\hline 1 & $5.0(-1)$ & $24(-1)$ & $35(-1)$ & $2(-1)$ & 0.203 & 0.190 \\
\hline 2 & $6.0(1)$ & $24(-1)$ & $35(-1)$ & $2(-1)$ & 0.154 & 0.261 \\
\hline 3 & $5.0(-1)$ & $48(1)$ & $35(-1)$ & $2(-1)$ & 0.233 & 0.277 \\
\hline 4 & $6.0(1)$ & $48(1)$ & $35(-1)$ & $2(-1)$ & 0.202 & 0.234 \\
\hline 5 & $5.0(-1)$ & $24(-1)$ & $45(1)$ & $2(-1)$ & 0.023 & 0.195 \\
\hline 6 & $6.0(1)$ & $24(-1)$ & $45(1)$ & $2(-1)$ & 0.421 & 0.367 \\
\hline 7 & $5.0(-1)$ & $48(1)$ & $45(1)$ & $2(-1)$ & 0.321 & 0.260 \\
\hline 8 & $6.0(1)$ & $48(1)$ & $45(1)$ & $2(-1)$ & 0.345 & 0.319 \\
\hline 9 & $5.0(-1)$ & $24(-1)$ & $35(-1)$ & $4(1)$ & 0.011 & 0.166 \\
\hline 10 & $6.0(1)$ & $24(-1)$ & $35(-1)$ & $4(1)$ & 0.249 & 0.286 \\
\hline 11 & $5.0(-1)$ & $48(1)$ & $35(-1)$ & $4(1)$ & 0.435 & 0.464 \\
\hline 12 & $6.0(1)$ & $48(1)$ & $35(-1)$ & $4(1)$ & 0.512 & 0.470 \\
\hline 13 & $5.0(-1)$ & $24(-1)$ & $35(-1)$ & $4(1)$ & 0.608 & 0.551 \\
\hline 14 & $6.0(1)$ & $24(-1)$ & $45(1)$ & $4(1)$ & 0.687 & 0.772 \\
\hline 15 & $5.0(-1)$ & $48(1)$ & $45(1)$ & $4(1)$ & 0.804 & 0.826 \\
\hline 16 & $6.0(1)$ & $48(1)$ & $45(1)$ & $4(1)$ & 0.945 & 0.934 \\
\hline 17 & $6.5(-2)$ & $36(0)$ & $45(1)$ & $3(0)$ & 0.207 & 0.114 \\
\hline 18 & $7.0(2)$ & $36(0)$ & $40(0)$ & $3(0)$ & 0.304 & 0.292 \\
\hline 19 & $5.5(0)$ & $12(-2)$ & $40(0)$ & $3(0)$ & 0.328 & 0.164 \\
\hline 20 & $5.5(0)$ & $60(2)$ & $40(0)$ & $3(0)$ & 0.354 & 0.413 \\
\hline 21 & $5.5(0)$ & $36(0)$ & $30(-2)$ & $3(0)$ & 0.344 & 0.222 \\
\hline 22 & $5.5(0)$ & $36(0)$ & $50(2)$ & $3(0)$ & 0.674 & 0.691 \\
\hline 23 & $5.5(0)$ & $36(0)$ & $40(0)$ & $1(-2)$ & 0.445 & 0.397 \\
\hline 24 & $5.5(0)$ & $36(0)$ & $40(0)$ & $5(2)$ & 1.046 & 0.368 \\
\hline 25 & $5.5(0)$ & $36(0)$ & $40(0)$ & $3(0)$ & 0.433 & 0.368 \\
\hline 26 & $5.5(0)$ & $36(0)$ & $40(0)$ & $3(0)$ & 0.365 & 0.368 \\
\hline 27 & $5.5(0)$ & $36(0)$ & $40(0)$ & $3(0)$ & 0.387 & 0.368 \\
\hline 28 & $5.5(0)$ & $36(0)$ & $40(0)$ & $3(0)$ & 0.398 & 0.368 \\
\hline 29 & $5.5(0)$ & $36(0)$ & $40(0)$ & $3(0)$ & 0.125 & 0.368 \\
\hline 30 & $5.5(0)$ & $36(0)$ & $40(0)$ & $3(0)$ & 0.366 & 0.368 \\
\hline 31 & $5.5(0)$ & $36(0)$ & $40(0)$ & $3(0)$ & 0.500 & 0.368 \\
\hline
\end{tabular}

Table 3 


\begin{tabular}{llllll}
\hline Source & DF & Seq SS & Adj. MS & F-value & $p$-value \\
\hline Regression & 14 & 1.50048 & 0.10718 & 7.39 & 0.000 \\
Linear & 4 & 0.99625 & 0.24906 & 17.17 & 0.000 \\
\hline Square & 4 & 0.28970 & 0.07243 & 4.99 & 0.008 \\
\hline Interaction & 6 & 0.21453 & 0.03576 & 2.46 & 0.070 \\
\hline Residual Error & 16 & 0.23210 & 0.01451 & & \\
\hline Lack-of-Fit & 10 & 0.15013 & 0.01501 & 1.10 & 0.475 \\
\hline Pure Error & 6 & 0.08197 & 0.01366 & & \\
\hline Total & 30 & 1.73258 & & & \\
\hline
\end{tabular}

DF-degree of freedom; Seq SS-sequential sum of squares; Adj. MS-adjusted mean squares;

Table 4

\begin{tabular}{lllll}
\hline Terms & \multicolumn{1}{c}{ Coef } & SE Coef & $\mathrm{t}$-value & $\mathrm{p}$-value \\
\hline$\beta_{0}$ & 0.367714 & 0.04552 & 8.078 & 0.000 \\
$\beta_{1}$ & 0.044625 & 0.02458 & 1.815 & 0.088 \\
\hline$\beta_{2}$ & 0.0662208 & 0.02458 & 2.530 & 0.022 \\
\hline$\beta_{3}$ & 0.117292 & 0.02458 & 4.771 & 0.000 \\
\hline$\beta_{4}$ & 0.147958 & 0.02458 & 6.018 & 0.000 \\
\hline$\beta_{11}$ & -0.041085 & 0.02252 & -0.824 & 0.087 \\
\hline$\beta_{22}$ & -0.019710 & 0.02252 & -0.875 & 0.394 \\
\hline$\beta_{33}$ & 0.022290 & 0.02252 & 0.990 & 0.337 \\
\hline$\beta_{44}$ & 0.081415 & 0.02252 & 3.615 & 0.002 \\
\hline$\beta_{12}$ & -0.028438 & 0.03011 & -0.944 & 0.359 \\
\hline$\beta_{13}$ & 0.025438 & 0.03011 & 0.845 & 0.411 \\
\hline$\beta_{14}$ & 0.012062 & 0.03011 & 0.401 & 0.694 \\
\hline$\beta_{23}$ & -0.005563 & 0.03011 & -0.185 & 0.856 \\
\hline$\beta_{24}$ & 0.052563 & 0.03011 & 1.746 & 0.100 \\
\hline$\beta_{34}$ & 0.094938 & 0.03011 & 3.153 & 0.006 \\
\hline
\end{tabular}

Coef-coefficient; SE Coef-standard error coefficient

\section{Figures}




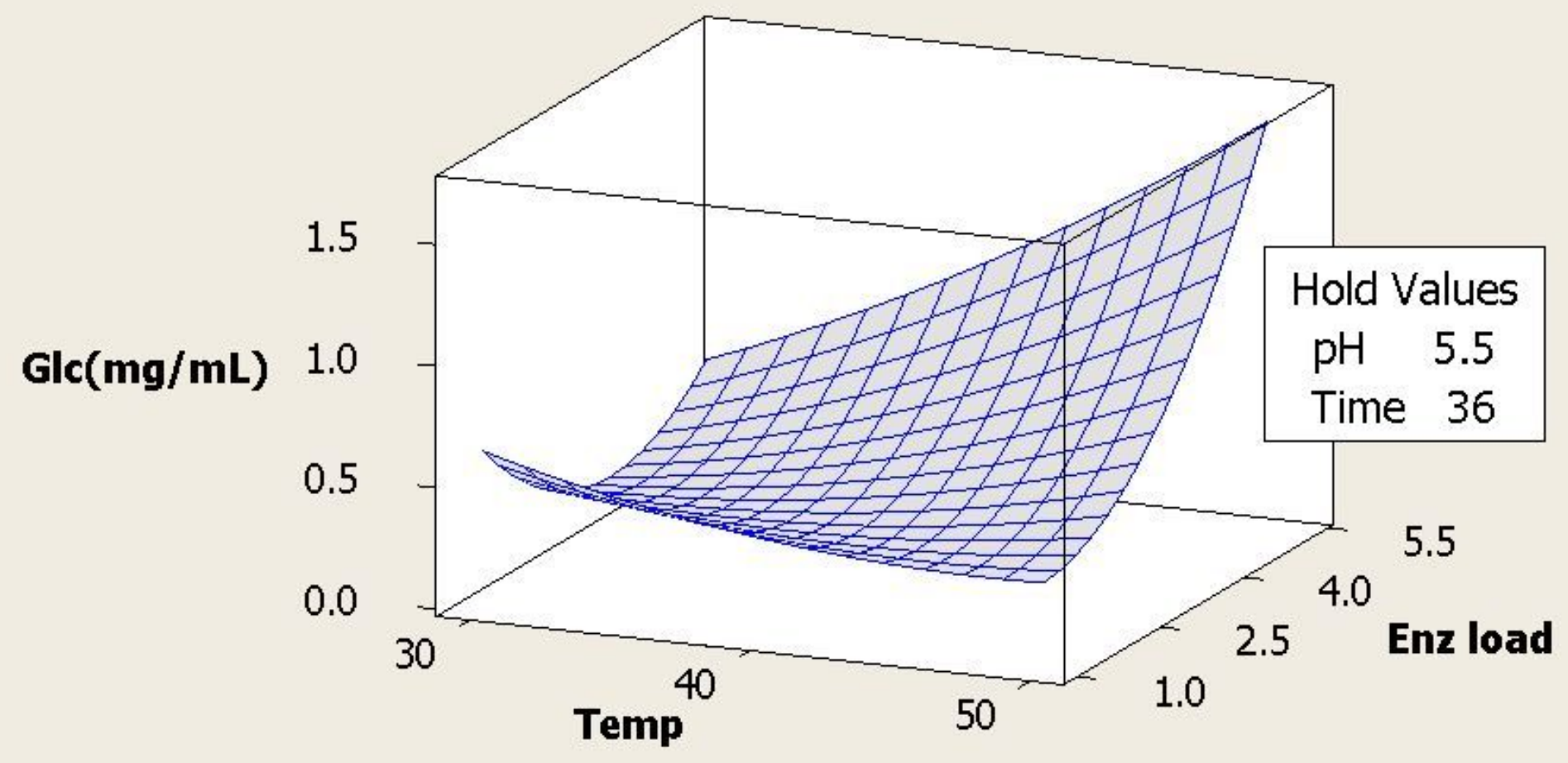

Figure 1

Response surface plot of the combined effect of reaction time and enzyme concentration on glucose yield.

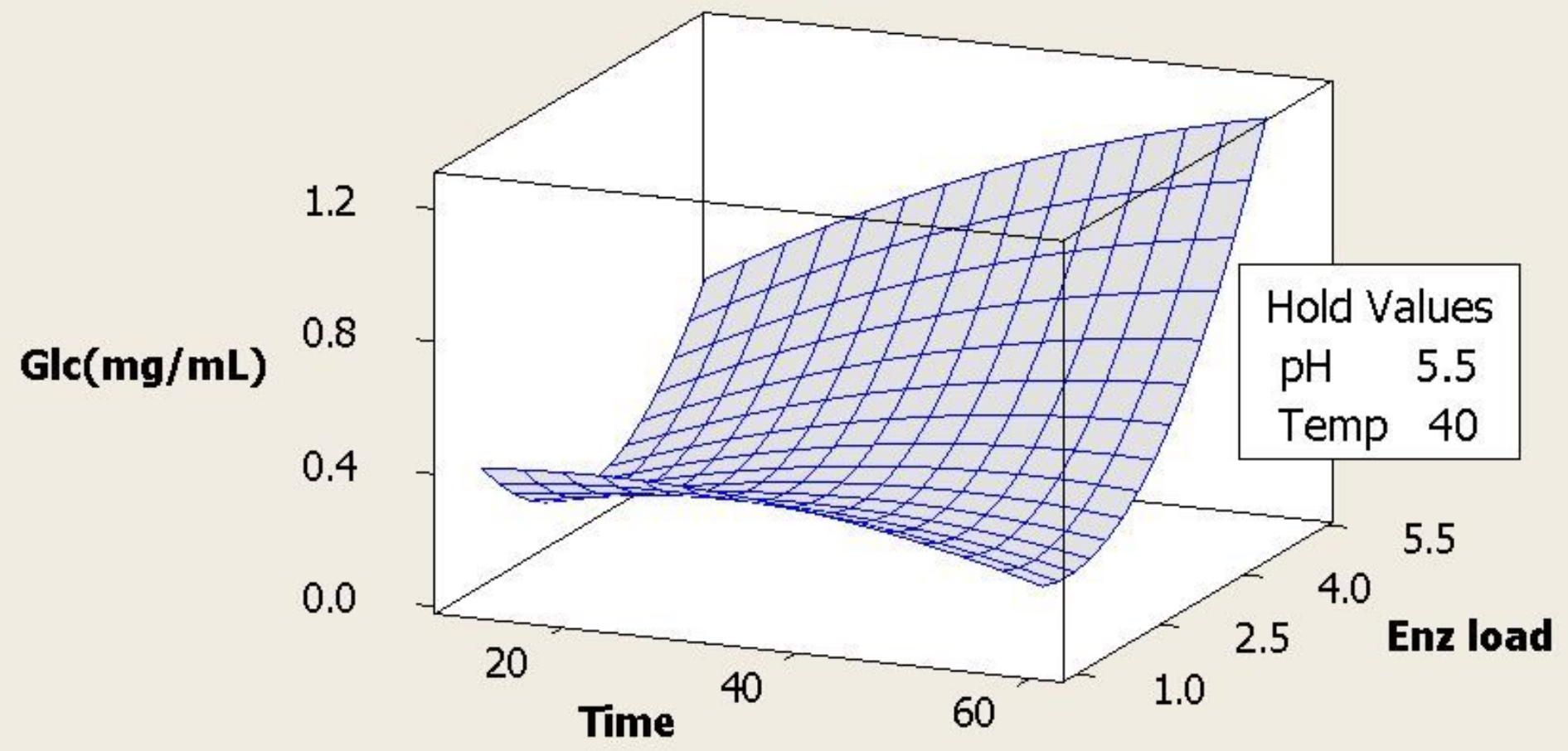

Figure 2 
Response surface plot of the combined effect of time and enzyme loading on glucose yield

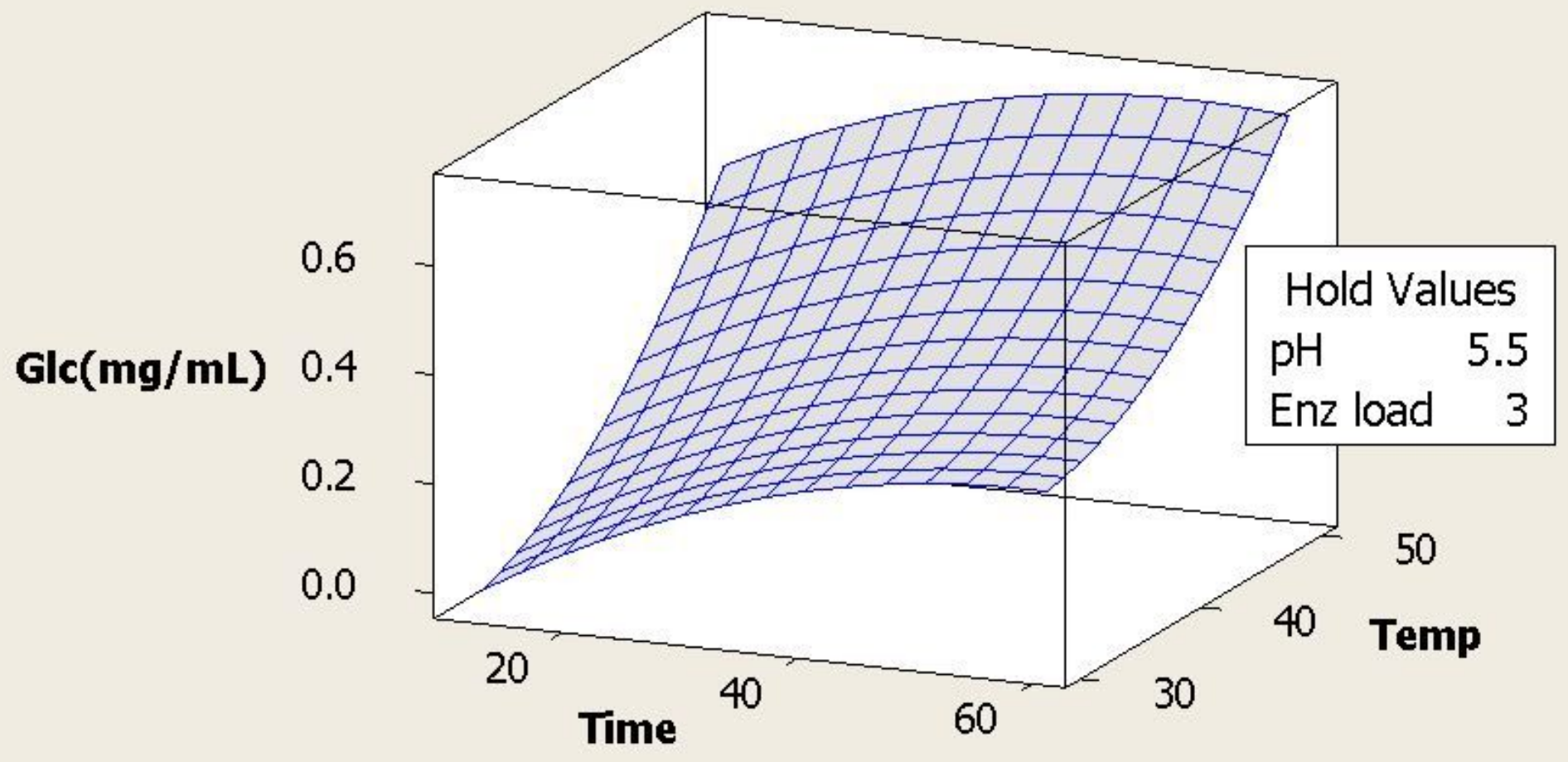

Figure 3

Response surface plot of the combined effect of temperature and time on glucose yield

$\operatorname{Glc}(\mathbf{m g} / \mathrm{mL})$

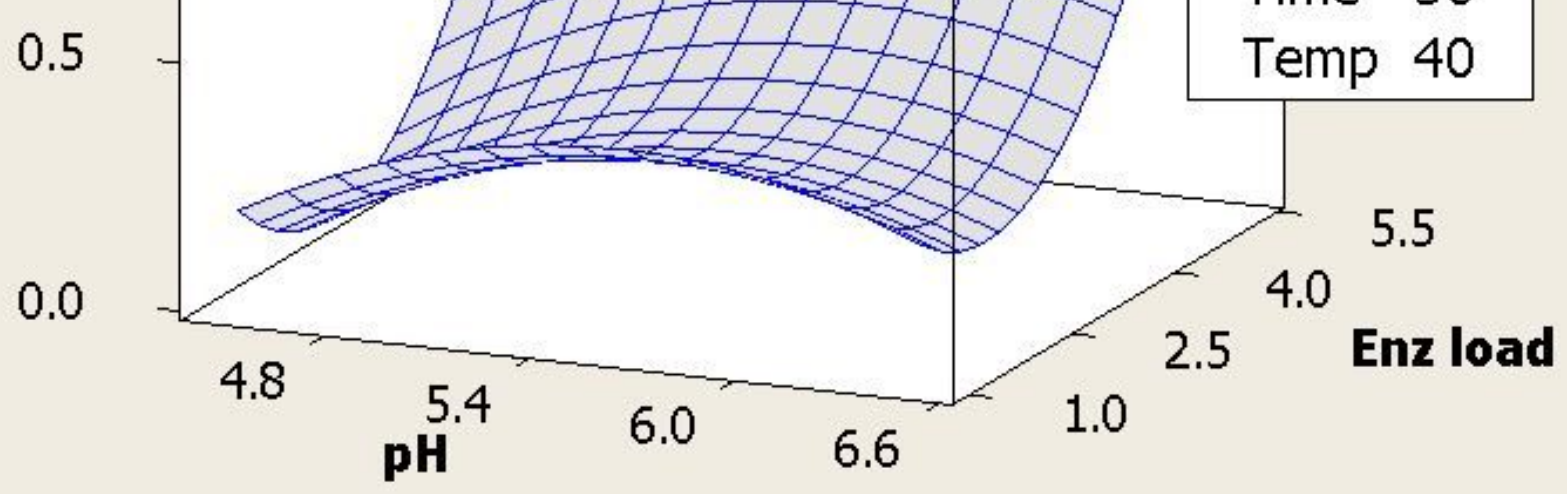


Figure 4

Response surface plot of the combined effect of enzyme load and temperature on glucose yield

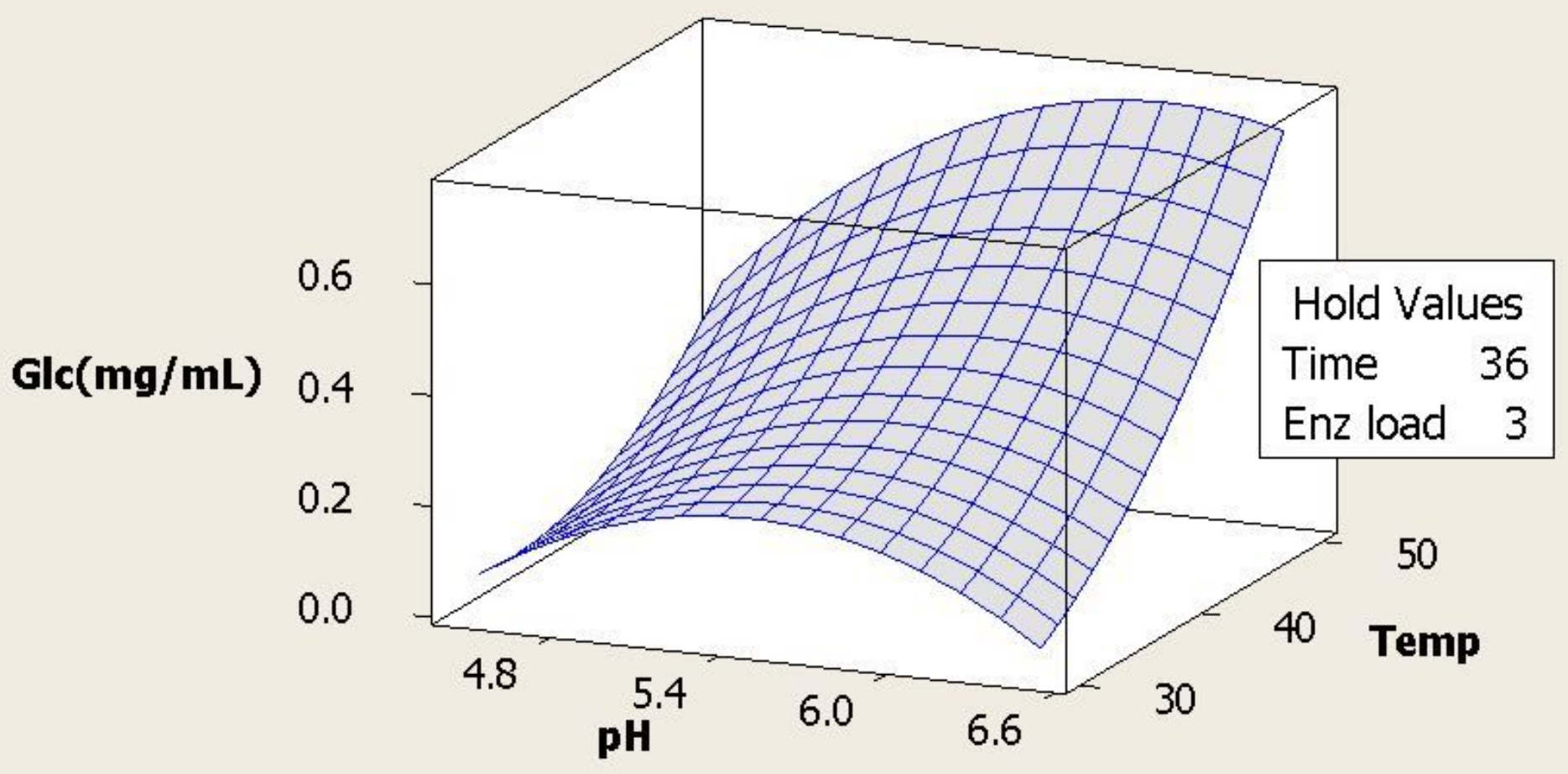

\section{Figure 5}

Response surface plot of the combined effect of $\mathrm{pH}$ and time on glucose yield 


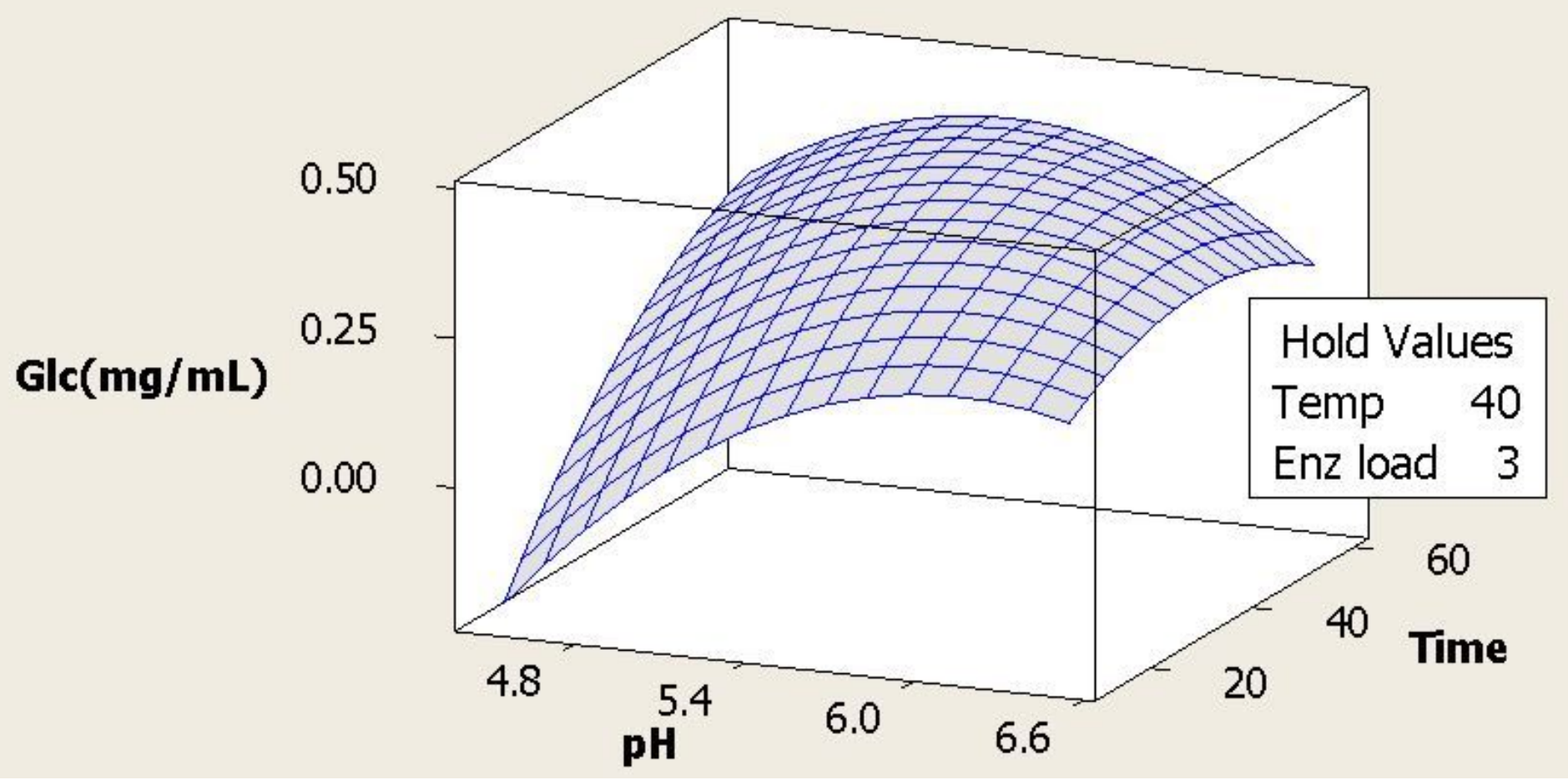

Figure 6

Response surface plot of the combined effect of temperature and time on glucose yield

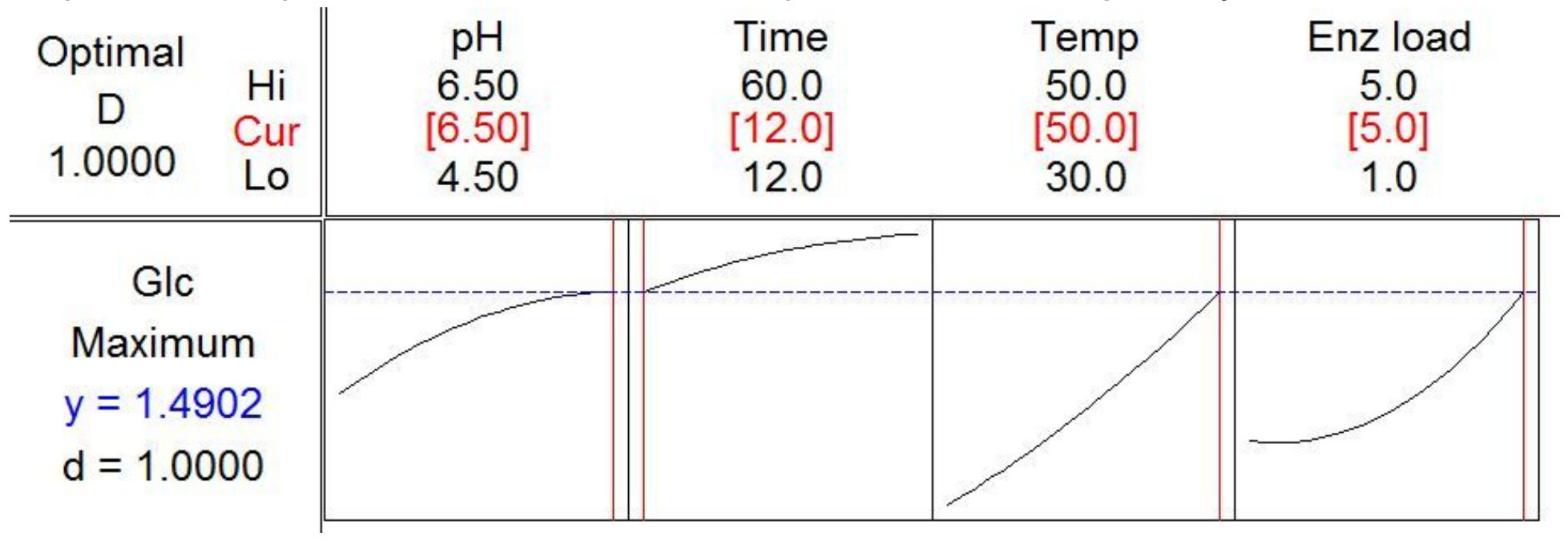

Figure 7

Optimization plot for enzymatic saccharification of mushroom 